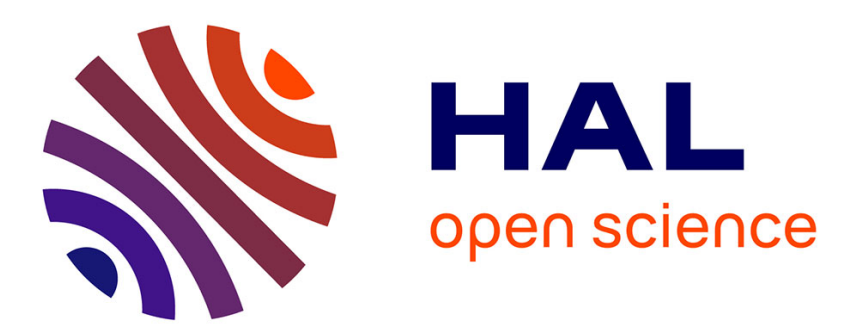

\title{
Relationship between the erosion properties of soils and other parameters
}

Robin Fell, Gregory Hanson, Gontran Herrier, Didier Marot, Tony Wahl

\section{To cite this version:}

Robin Fell, Gregory Hanson, Gontran Herrier, Didier Marot, Tony Wahl. Relationship between the erosion properties of soils and other parameters. Erosion in Geomechanics Applied to Dams and Levees, 2013, 10.1002/9781118577165.ch5 . hal-01007538

\section{HAL Id: hal-01007538 \\ https://hal.science/hal-01007538}

Submitted on 8 Dec 2017

HAL is a multi-disciplinary open access archive for the deposit and dissemination of scientific research documents, whether they are published or not. The documents may come from teaching and research institutions in France or abroad, or from public or private research centers.
L'archive ouverte pluridisciplinaire HAL, est destinée au dépôt et à la diffusion de documents scientifiques de niveau recherche, publiés ou non, émanant des établissements d'enseignement et de recherche français ou étrangers, des laboratoires publics ou privés. 


\section{Relationship between the Erosion Properties of Soils and Other Parameters}

Robin Fell, Gregory Hanson, Gontran HERRIER, Didier Marot and Tony WAHL

\subsection{Introduction}

This chapter discusses the relationships between the erosion properties of soils and the following soil properties:

- unified soil classification;

- degree of compaction, moisture content and the degree of saturation at the time of compaction and in service;

- dispersivity and slaking properties of the soil and how this relates to clay mineralogy and the chemistry of the water;

- soil texture and structure that are related to compaction conditions.

In this chapter, we have also discussed the following:

- the effects of test methods on erosion properties; 
- how the critical shear stress and erosion rate for dispersive soils can be modified by adding lime, gypsum or cement and the mechanics of this change.

The discussion is related mainly to soils in engineered fills, but some of the discussion is applicable to soils in situ. It applies to internal erosion of plastic and non-plastic soils by a concentrated leak.

Some of the discussion is applicable to naturally occurring soils in dam and levee foundations and to unlined spillways in soil.

\subsection{Definitions of soil erosion properties and the relationships between them}

Soil erodibility is most commonly described in the literature by the excess stress equation [TEM 85, HAN 89, WAN 04a, WAN 04b]. The relationship is often expressed as the rate of erosion in terms of either volume per unit area per unit of time or mass per unit area per unit of time. For volume per unit of time, the following expression is defined:

$$
E_{r}=k_{d}\left(\tau_{e}-\tau_{c}\right)
$$

where $E_{r}$ is the rate of erosion $(\mathrm{m} / \mathrm{s}), k_{d}$ is the detachment/erodibility coefficient $\left(\mathrm{cm}^{3} / \mathrm{N}-\mathrm{s}\right), \quad \tau_{e}$ is the hydraulic shear stress $\left(\mathrm{N} / \mathrm{m}^{2}\right)$ and $\tau_{c}$ is the critical stress $\left(\mathrm{N} / \mathrm{m}^{2}\right)$.

The erodibility coefficient $k_{d}$ reported in $\mathrm{cm}^{3} / \mathrm{N}-\mathrm{s}$ by Hanson and Cook [HAN 04] has been observed to range in value from 0.001 to 1000 . Low values indicate erosion resistant soils and high values indicate erodible soils.

For mass per unit of time, a similar expression can be defined:

$$
E_{t}=C_{e}\left(\tau_{e}-\tau_{c}\right)
$$


where $E_{t}$ is the rate of erosion $\left(\mathrm{kg} / \mathrm{s} / \mathrm{m}^{2}\right)$ and $C_{e}$ is the detachment/erodibility coefficient $(\mathrm{s} / \mathrm{m})$. A comparison of equations [5.1] and [5.2] gives $C_{e}=k_{d} / \rho_{d}$, where $\rho_{d}$ is the dry density $\left(\mathrm{kg} / \mathrm{m}^{3}\right)$.

Since the erodibility coefficient can vary over several orders of magnitude, Wan and Fell [WAN 04a] proposed an erosion rate index $(I)$ defined as the $-\log \left(C_{e}\right)$ which ranges from 0 to 6 .

An erosion rate index of two or less implies a very rapidly erodible soil and a high value of five or more implies a low rate of erosion. Table 5.1 presents values of $k_{d}$ and $C_{e}$ [HAN 10a] along with the corresponding erosion rate index and qualitative resistance class as proposed by Wan and Fell [WAN 04a]).

\begin{tabular}{|c|c|c|c|c|}
\hline$k_{d}\left(\mathrm{~cm}^{3} / \mathrm{N}-\mathrm{s}\right)$ & $\begin{array}{c}C_{e} \\
(\mathrm{~s} / \mathrm{m})^{1}\end{array}$ & $\begin{array}{c}I= \\
-\log \left(C_{e}\right)^{1}\end{array}$ & $\begin{array}{c}\text { Erosion } \\
\text { Rate } \\
\text { Index }\end{array}$ & $\begin{array}{c}\text { Qualitative } \\
\text { Description }^{2}\end{array}$ \\
\hline 1000 & $5 \times 10^{-1}-7 \times 10^{-1}$ & $0.2-0.3$ & 0 & $\begin{array}{c}\text { Extremely } \\
\text { rapid }\end{array}$ \\
\hline 100 & $5 \times 10^{-2}-7 \times 10^{-2}$ & $1.2-1.3$ & 1 & $\begin{array}{c}\text { Extremely } \\
\text { rapid }\end{array}$ \\
\hline 10 & $5 \times 10^{-3}-7 \times 10^{-3}$ & $2.2-2.3$ & 2 & Very rapid \\
\hline 1 & $5 \times 10^{-4}-7 \times 10^{-4}$ & $3.2-3.3$ & 3 & $\begin{array}{c}\text { Moderately } \\
\text { rapid }\end{array}$ \\
\hline 0.1 & $5 \times 10^{-5}-7 \times 10^{-5}$ & $4.2-4.3$ & 4 & $\begin{array}{c}\text { Moderately } \\
\text { slow }\end{array}$ \\
\hline 0.01 & $5 \times 10^{-6-7 \times 10^{-6}}$ & $5.2-5.3$ & 5 & Very slow \\
\hline 0.001 & $5 \times 10^{-7}-7 \times 10^{-7}$ & $6.2-6.3$ & 6 & Extremely slow \\
\hline
\end{tabular}

1 Based on the range of $\rho$ from 1,500 to $2,000 \mathrm{~kg} / \mathrm{m}^{3}$.

2 Erosion rate index and qualitative description grouping based on [WAN 04a].

Table 5.1. Relationship between $k_{d}, C_{e}, I$, erosion rate index and qualitative erosion resistance [HAN 10a] 
The value of the erodibility/soil detachment coefficient provides an indication of how quickly surface erosion in overtopping will occur or internal erosion will develop within cracks or other openings in an embankment subjected to hydraulic stress.

\subsection{Effects of test methods on soil erosion properties}

\subsubsection{Effect of testing methods on erosion rate}

Wahl et al. [WAH 08] carried out tests where identically prepared remolded soil samples were tested by the hole erosion test (HET) and jet erosion test (JET). They found that both methods ranked the soils similarly for their relative erodibility, but the JET method indicated a higher rate of erosion, up to one or more orders of magnitude, and lower critical shear stresses, by up to two or more orders of magnitude.

Wahl et al. [WAH 08] speculated that differences between the erosion rates observed in the two tests were related to several factors, including:

- differences in the nature of the hydraulic attack upon the eroding surface in each test;

- differences in the way that the flow exploits different weaknesses in the soil structure;

- differences in the geometry of the exposed soil surface;

- inaccurate or incomplete analytical models for the stress distributions produced at the soil surface;

- use of a linear erosion model for analysis when erosion rate versus applied stress may actually be nonlinear;

- performing tests in different stress ranges and with an opposite progression of applied stress (high to low in JET, 
typically well above the critical stress and low to high in HET, beginning near the critical stress level).

Briaud [BRI 08a, BRI 08b] suggests that soil erodibility may depend fundamentally on three different types of hydraulic attacks: pure shear stress, turbulent fluctuations of shear stress and turbulent fluctuations of normal stress. Wahl et al. [WAH 08b] discussed the fact that we analyze each test by attempting to relate only the applied shear stress to the erosion rate, but other forms of hydraulic attack may be significant and may have different degrees of influence in different test environments.

The range of soil types and compaction conditions for the tests by Wahl et al. [WAH 08b] was limited, but the greatest differences seemed to occur in samples with a coarse or nonuniform soil structure (generally samples containing more clay and significantly compacted dry of optimum water content). This suggested that the JET is more sensitive to soil fabric, perhaps because the stress environment produced by the impinging jet is more readily able to exploit weak zones in a non-uniform soil structure. This may also be related to the different geometry of the exposed soil surface in each test, a planar surface in the JET versus a small, confined hole for the HET. Aggregates of soil particles that can be dislodged and removed in the JET environment may be held in place by the surrounding soil mass in the HET.

Lim [LIM 06], Lim and Khalili [LIM 09] investigated the erosion properties of soils using the rotating cylinder test (RCT) and HET. In the RCT, the erosion is from the vertical sides of a sample measuring $100 \mathrm{~mm}$ (diameter) by $100 \mathrm{~mm}$ (height). Figure 5.1 shows a comparison between the erosion rate indices for these tests. It can be seen that dispersive soils have a good correlation with the HET giving a slightly larger index (slower rate of erosion). However, there is a large difference for the non-dispersive soils, with the RCT giving rates $10-15$ times those obtained using the HET. 
Lim attributes this to the vertical face of the RCT, and to surface and/or body slaking occurring in the RCT which could not occur in the HET because of the relatively large size of the slaking particles and the small hole in the HET [LIM 06]. They also noted that fabric was important in the RCT with samples, dry of the optimum, having a blocky fabric. Figure 5.1 also includes the results of JET tests carried out by Wahl et al. [WAH 08b] indicating some similarity between the RCT and JET results relative to the HET.

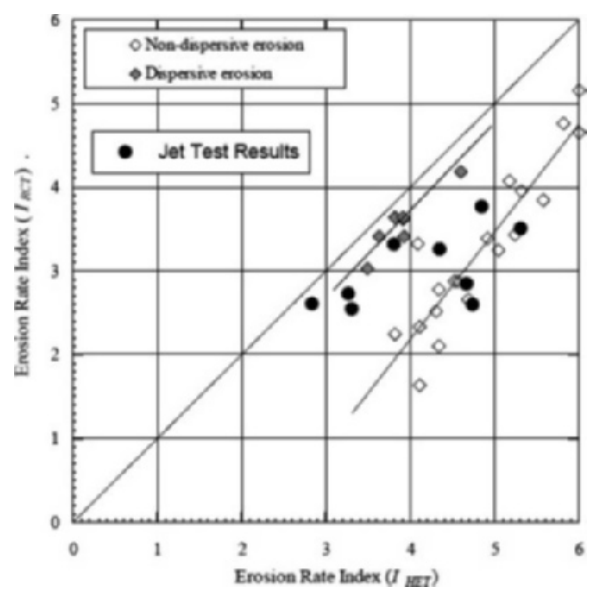

Figure 5.1. Correlation between the erosion rate indices of rotating cylinder and hole erosion tests [LIM 06] and the results of superimposed jet erosion tests [WAH 08b]

The HET and slot erosion test (SET) [WAN 02, WAN 04a] model erosion conditions in a crack and pipe in the early stages of development but may underestimate the rate of erosion as the pipe develops and the size allows the mechanisms modelled in the RCT and JET to take effect. That is, the larger blocky aggregated soil particles can erode as the hole enlarges. This could be allowed for by using a varying erosion rate index when calculating the rate of the enlargement of a pipe. However, to conclude that the scale 
effect is the correct reason, one should perform HET or SET testing on larger scales and prove that the size of the hole changes the process and the results. The only conclusion we can currently make is that the two tests (HET/SET vs. JET) in their current configurations produce different results. Further research is needed to explain the reason.

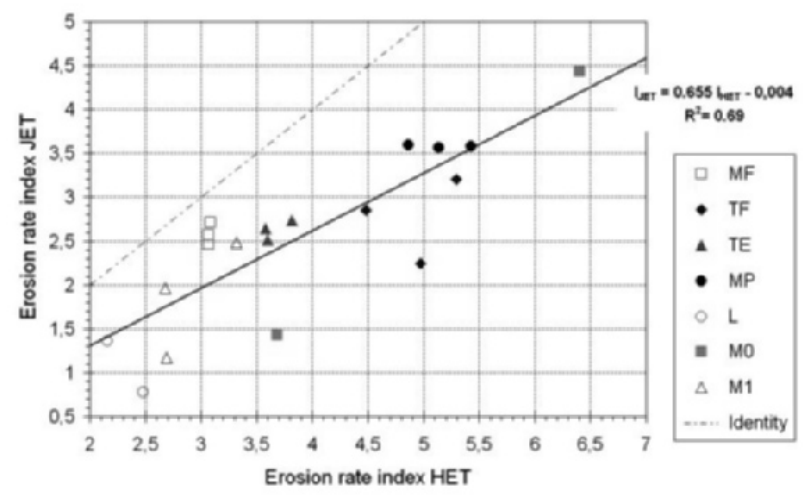

Figure 5.2. Erosion rate index values measured with the JET versus values measured with the HET [REG 13]

Regazzoni and Marot [REG 13] tested fine-grained soils covering a large range of erodibility. Soils were prepared for JET and HET testing using methods described in the Bureau of Reclamation Earth Manual (1990) for a total number of 19 tests with each device. Hanson and Cook's analysis [HAN 04] and Bonelli and Brivois' scaling law [BON 08] were used to analyze JET and HET, respectively. They showed that the values of the erosion coefficient are systematically higher with the JET than with the HET and the corresponding mean rate index is systematically smaller with the JET (IJET) than with the HET $\left(I_{H E T}\right)$. Moreover, as shown in Figure 5.2, the relative classification of the erodibility based on the values of erosion rate index yielded by both apparatus is not exactly the same. If we consider the erosion rate index determined by JET, nearly identical values are obtained for 
soils MF, TE, and TF, whereas if we consider the erosion rate index determined by HET, a clear difference appears. $\mathrm{MF}$ is the most erodible soil, followed by $\mathrm{TE}$, and $\mathrm{TF}$ is the least erodible soil.

Marot et al. [MAR 11] proposed a new analysis which is based on the fluid energy expended $\left(E_{\text {erosion }}\right)$ and the eroded dry mass $\left(m_{d r y}\right)$. The erosion resistance index is defined as $\log \left(E_{\text {erosion }} / m_{d r y}\right)$. The values of erosion resistance index obtained for tested fine soils are roughly the same with JET and HET devices.

\subsubsection{Effect of testing methods on critical shear stress $\left(\tau_{c}\right)$}

The critical shear stress that initiates erosion $\left(\tau_{\mathrm{c}}\right)$ is a difficult property to measure. Lim [LIM 06] and Lim and Khalili [LIM 09] found that the form of the hydraulic shear stress versus erosion rate plot varies for different soils, behaving bilinearly and others exhibiting simple linear relations with intercepts on the " $\mathrm{X}$ " and " $\mathrm{Y}$ " axes as shown in Figure 5.3.

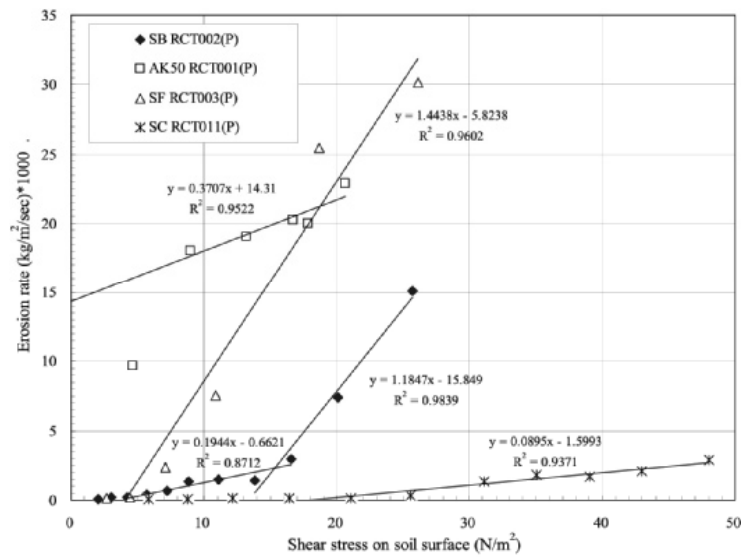

Figure 5.3. Typical erosion behavior of unsaturated non-dispersive clay soils [LIM 06] 
Wan and Fell [WAN 02, WAN 04a] had similar problems and this is why they adopted the procedure of varying heads in the HET to define the critical shear stress, which they termed the initial shear stress, $\tau_{0}$.

The extrapolation of the plots in Lim [LIM 06] to the "X" axis for the RCT on non-dispersive soils gives critical shear stresses which are similar to the initial shear stresses (from HET) up to erosion indexes indices of four. Lim [LIM 06] did not test many soils with erosion rate indices greater than four, but those he did test appeared to give somewhat lower critical shear stresses than the HET. This may reflect the occurrence of slaking of larger particles on the surface of the RCT samples. Wahl et al. [WAH 08] also made the same observations relative to the JET and HET.

Regazzoni and Marot [REG 13] obtained critical shear stresses for the soils in Figure 5.2 as shown in Figure 5.3. They found that the critical shear stress from the JET were often much lower than for the HET.

The values of critical shear stress for the HET are rather high for soils MP and TF compared to their erosion rate indices. The JET critical shear stress values are much lower and seem too low. Wan and Fell [WAN 02, WAN 04a] performed SET and HET tests on soils with erosion rate indices of approximately five-six in the laboratory and their behavior was not consistent with such low critical shear stresses.

The reason for this and the low values found by Lim [LIM 06] for some soils needs further research.

Benahmed et al. [BON 08, BEN 12a, BEN 12b] have refined the HET and developed an improved method for determining critical shear stress. This involves testing at a 
constant flow rate rather than at a constant head as used by Wan and Fell [WAN 04a]. The critical shear stress is obtained at the end of the test when no further erosion occurs.

The only potential issue with this is that the eroding surface is more likely to be saturated using this method than for the Wan and Fell [WAN 04a] method, and if the critical shear stress is increased with the degree of saturation, it may be overestimated for the soil in its compacted condition.

Further research is needed to determine whether HET performed at a constant flow rate and at a constant head give similar results for initially unsaturated specimens.

The roughness of the eroding surface is likely to affect the critical shear stress determination in both the HET and JET although the magnitude of the sensitivity to roughness is not well quantified. In the HET, the critical shear stress using the Bonelli et al. approach [BON 08] is determined considering conditions throughout the test; so, this effect is at least partially overcome. In the Wan and Fell method [WAN 04a], the critical shear is determined from the erosion observed early in the test, while the surface is likely to be relatively smooth; so, the value is representative of a smooth-surface condition. In the JET, the critical shear stress value is determined based on an extrapolation of the equilibrium depth of erosion that would occur after infinite time; so, the result is likely to be most affected by conditions near the end of the test when there is a rough-surface condition. For remolded samples, JET results can also vary depending on whether the upper or lower surface is tested. The compaction conditions and roughness of the surface can both vary as a result of specific compaction and sample preparation procedures. 


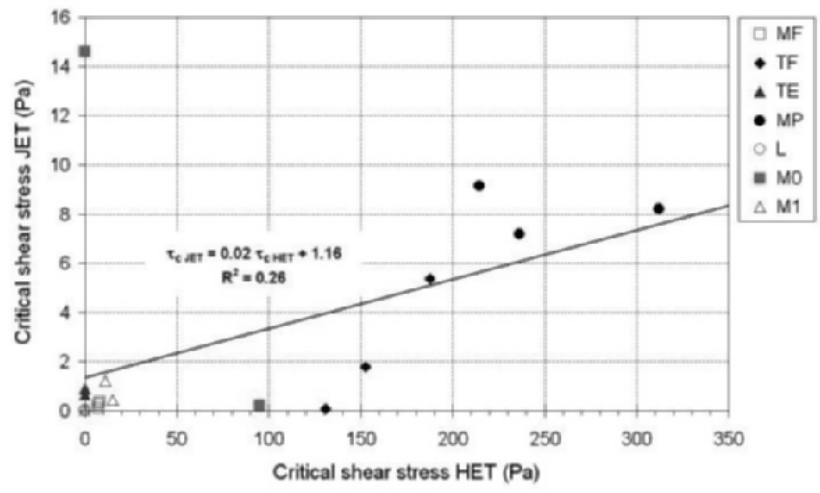

Figure 5.4. Critical shear stress values measured with the JET versus values measured with the HET [REG 13]

\subsubsection{Correlation between critical shear stress and erosion rate index}

The critical shear stress is related to the erosion rate index. Figure 5.5 shows data from HET obtained by Wan and Fell [WAN 04a] and others. Table 5.2 is developed from these data. It gives only approximate estimates of the likely range of critical shear stress $\left(\tau_{c}\right)$ and should be used with caution when HET values are not available.

The critical shear stress for dispersive soils is likely to be only 1 or $2 \mathrm{~N} / \mathrm{m} 2$.

Hanson and Simon [HAN 01] developed a correlation between $k_{d}$ and $\tau_{c}$ for JET, and Wahl et al. [WAH 08b] showed that a similar relationship existed for both JET and HET data.

It is emphasized that it is better to perform a series of HET tests at varying heads or to use the method of Bonelli ([BON 08], Chapter 4 of this book) to define the critical shear stress $\left(\tau_{c}\right)$ than to rely on these relationships. 


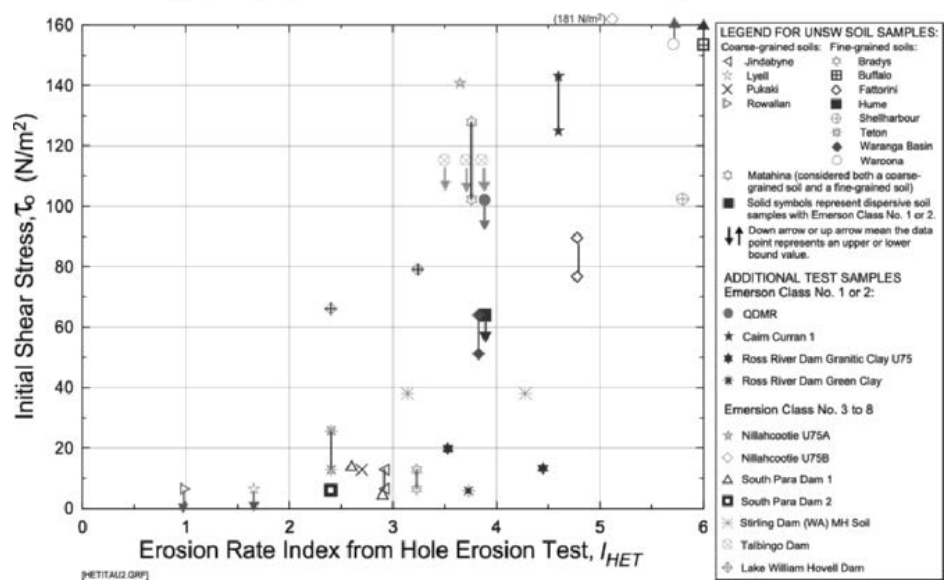

Figure 5.5. Initial shear stress ( $\tau_{0}$.) versus representative erosion rate index $\left(I_{\text {HET }}\right)$ for soils which are non-dispersive and for dispersive soils with eroding water suppressing dispersion

(Courtesy of C.F.Wan)

\begin{tabular}{ccccc}
\hline & \multicolumn{4}{c}{ Critical Shear Stress $\tau_{c}$ Pa } \\
\cline { 2 - 5 } $\begin{array}{c}\text { Hole } \\
\text { Erosion } \\
\text { Index } I_{H E T}\end{array}$ & \multicolumn{2}{c}{$\begin{array}{c}\text { Non-Dispersive Soil } \\
\text { Behavior }\end{array}$} & Dispersive Soil Behavior \\
\cline { 2 - 5 } & $\begin{array}{c}\text { Best } \\
\text { Estimate }\end{array}$ & $\begin{array}{c}\text { Likely } \\
\text { Range }\end{array}$ & $\begin{array}{c}\text { Best } \\
\text { Estimate }\end{array}$ & $\begin{array}{c}\text { Likely } \\
\text { Range }\end{array}$ \\
\hline$<2$ & 2 & $1-5$ & 1 & $0.5-2$ \\
$2-3$ & 2 & $1-5$ & 1 & $0.5-2$ \\
3.5 & 5 & $2-20$ & 2 & $1-5$ \\
4 & 25 & $10-50$ & 5 & $2-10$ \\
5 & 60 & $25-100$ & 5 & $2-10$ \\
6 & 100 & $60-140$ & 5 & $2-10$ \\
\hline
\end{tabular}

Note: This table should be used with caution. For important decisions, perform hole erosion tests to determine the initial shear stress $\left(\tau_{c}\right)$.

Table 5.2. Estimated values and likely range of critical shear stress $(\tau)$ versus hole erosion index $\left(I_{H E T}\right)$ for non-dispersive soils [FEL 08] 


\subsection{Relationship to field performance}

\subsubsection{JET tests done in the laboratory and in the field}

Hanson and Hunt [HAN 07] carried out JET tests in the laboratory and in the field on soils compacted to a range of water contents. The results are shown in Figure 5.6. It can be seen that the laboratory and field results are similar, thus confirming the value of the JET for performing tests on in situ soils.

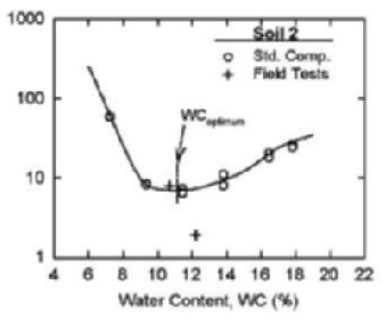

a)

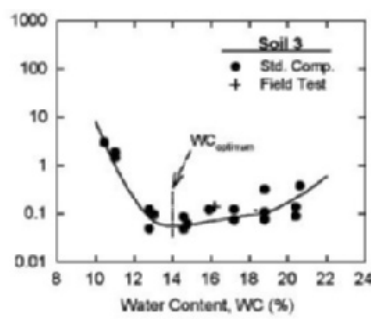

b)

Figure 5.6. Comparison of erodibility determined from Jet Erosion Tests (JET) tests in the laboratory and field tests for a) soil 2 - non-plastic SM and b) soil 3 CL soil with a plasticity index of 17 [HAN 07]

\subsubsection{Assessment of rates of erosion from JET and large-scale laboratory tests}

Hanson and Hunt [HAN 07] conducted a series of bench scale laboratory JET tests and large-scale laboratory tests on breach widening. They measured the impact of changes in the compaction water content of two soils compacted at standard compaction on the erodibility coefficient. Figure 5.7 shows a field experiment in progress and Figure 5.8 shows breach widening versus time. Wahl and Erdogan [WAH 08a] performed JET and HET tests on remolded samples of the soils used for additional tests of embankment breach via piping by Hanson et al. [HAN 10a]. They found that JET results were consistent with observed differences in the time scales of erosion and embankment breach for the tests, 
which spanned about two orders of magnitude. HET results also showed similar variation and consistency with the breach test results, but produced detachment rate coefficients, $k_{d}$, that were about one order of magnitude lower than the values obtained from companion JET tests. HET tests could not be performed on the non-plastic soils used for these breach tests because samples disintegrated before the tests could be completed. This typifies the conclusion by Wahl et al. [WAH 08b] that the HET in general can be reliably performed on soils exhibiting up to 2.8 orders of magnitude variation in $k_{d}$, but the JET can be successfully performed across nearly five orders of magnitude of $k_{d}$.

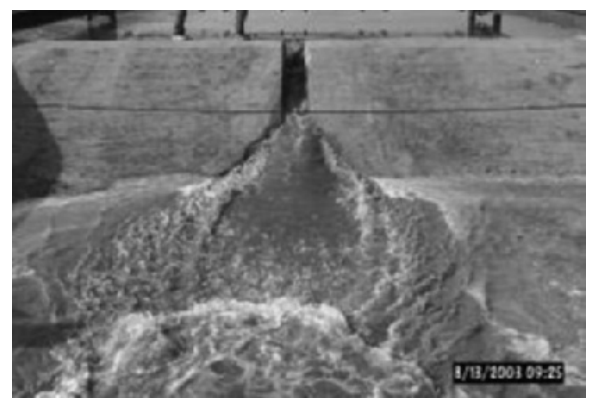

Figure 5.7. Large-scale outdoor laboratory experiment of breach widening [HAN 07]

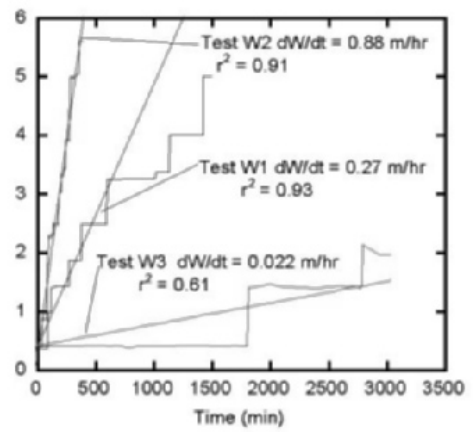

Figure 5.8. Breach widening versus time for two soils [HAN 07] 
It should be noted, however, that Wan and Fell [WAN 04a] were able to carry out HET for erosion rate indices from two to six including tests on silty sand of glacial and residual granite origins.

Wahl and Lentz [WAH 11] conducted laboratory-scale breach tests of canal embankments with embankment heights of $0.64 \mathrm{~m}$. In situ JET tests were performed on the embankments before and after breach testing and $k_{d}$ values were then related to measured and estimated rates of head cut advance and breach widening. The relation between $k_{d}$ and breach widening rates compared reasonably to a relation proposed by Hunt et al. [HUN 05] based on embankment breach widening tests.

The relation between head cut advance rates and $k_{d}$ compared well to a relation proposed by Hanson et al. [HAN 11] using data from earlier flume tests of head cut advance in which JET tests were also performed [HAN 01].

Bonelli developed this concept further by incorporating the maximum diameter of pipe that can be sustained before it collapses and breaches the dam or levee ([BON 11], Chapter 4 of this book). Reasonable correlations were found by inferring the erosion rate index from case data. On one large scale test, the erosion rate index found on an HET was used as a parameter of a dam-break model; the numerical result gave the order of magnitude of the time to failure (Chapter 4 of this book).

Fell et al. [FEL 08] have found that the rates of enlargement of pipes forming in a dam embankment predicted from HET are consistent with those observed in actual failures as reported by Fell et al. [FEL 03]. 


\subsection{Effects of the type of soil}

\subsubsection{General trends}

The erosion behavior of cohesionless soils is relatively simple. Once the tractive shear force overcomes the sliding or rolling resistance of the individual particles, the soil starts to erode. It can be evaluated in terms of the average grain diameter only, as illustrated in the Shields chart (1936).

In contrast, the erosion behavior of cohesive fine-grained soils is complex because of the electromagnetic and electrostatic inter-particle forces, which are influenced by the density, structure and fabric of the soil as well as the chemistry of the pore water, particle size distribution and clay mineralogy. The main physical parameters influencing the erosion of cohesive fine-grained soil are the particle size distribution (grain size), the clay fraction and the clay mineralogy. The complexity is increased by the fact that for a given soil, the erosion is also dependent on its mechanical state (density, moisture content, temperature).

Erosion resistance is highly dependent on the clay type and generally increases with increasing fine fraction or clay fraction. However, in general, no clear guidelines are established as to which parameters predominantly influence soil erosion under a certain physical condition, and there are some contradictory results for some of the parameters. Therefore, it is recommended to directly measure soil erodibility whenever possible. In situ tests or a laboratory test of intact samples are preferred because undisturbed natural clay samples tend to produce less erosion than remolded samples. 


\subsubsection{Relationship to soil classification}

In the absence of laboratory test values, the representative erosion rate index $\left(I_{H E T}\right)$, which is the erosion rate index for the soil compacted to $95 \%$ standard compaction ratio at optimum water content, can be related approximately to soil properties. Table 5.3 has been developed from test data in Wan [WAN 06] and some data from dam investigations to give a first approximation of the likely range of $I_{H E T}$ for different classifications of nondispersive soils.

\begin{tabular}{lccc}
\hline \multirow{2}{*}{$\begin{array}{c}\text { Unified Soil } \\
\text { Classification }\end{array}$} & \multicolumn{3}{c}{ Representative Erosion Rate Index $($ IHET $)$} \\
\cline { 2 - 4 } & $\begin{array}{c}\text { Likely } \\
\text { Minimum }\end{array}$ & $\begin{array}{c}\text { Best } \\
\text { Estimate }\end{array}$ & $\begin{array}{c}\text { Likely } \\
\text { Maximum }\end{array}$ \\
\hline SM with $<30 \%$ fines & 1 & $<2$ & 2.5 \\
SM with $>30 \%$ fines & $<2$ & $2-3$ & 3.5 \\
SC with $<30 \%$ fines & $<2$ & $2-3$ & 3.5 \\
SC with $>30 \%$ fines & 2 & 3 & 4 \\
ML & 2 & $2-3$ & 3 \\
CL-ML & 2 & 3 & 4 \\
CL & 3 & $3-4$ & 4.5 \\
CL-CH & 3 & 4 & 5 \\
MH & 3 & $3-4$ & 4.5 \\
CH with liquid limit $<65 \%$ & 3 & 4 & 5 \\
CH with liquid limit $>65 \%$ & 4 & 5 & 6 \\
\hline
\end{tabular}

Table 5.3. Representative erosion rate index $\left(I_{H E T}\right)$ versus soil classification for non-dispersive soils based on the study of Wan and Fell [WAN 02]

Wan [WAN 06] and Wan and Fell [WAN 02] used logistic regression to develop an equation relating the representative erosion rate index $\left(I_{H E T}\right)$ to other soil properties. The equation is based on limited data and those authors do not 
recommend that it be used. Table 5.3 shows a more reliable method. It is recommended to use best estimate values for best estimate probabilities and to check the sensitivity if the outcome is strongly dependent on the results. For important decisions, HET tests should be performed rather than relying on this table, which is very approximate.

\subsubsection{Effects of soil structure}

Lim [LIM 06] and Wahl et al. [WAH 08b] have noted that soil structure has an important effect on erosion properties. They found that erosion rates are significantly higher for the same soil if the soil is compacted dry of optimum moisture content and the soil forms aggregated particles and/or microcracks. These allow erosion of blocks of the soil rather than of the individual particles. The sensitivity to soil structure is thought to vary depending on the particular test used. This is believed to be one of the reasons that higher erosion rates are measured in JET than HET because the HET test is started with a relatively small hole diameter not allowing the "blocks" of soil to dislodge from the sides of the hole. This behavior was also noted in RCT tests by Lim [LIM 06]. The variability of soil structure versus compaction conditions probably is a function of soil type. Methods have not yet been well developed for describing soil structure in a quantitative way and relating measurable soil structure parameters to erodibility.

\subsection{Effects of compaction parameters}

\subsubsection{Relationship to compaction parameters}

The erosion resistance increases with increasing dry density and increasing water content (at the time of erosion testing). Table 5.3 does not address soils that are compacted dry or wet of optimum or that do not achieve the $95 \%$ 
standard compaction ratio. Two approaches to incorporate non-standard compaction effects have been taken, one relating erodibility to the end result of compaction (dry density) and the other relating erodibility to specific compaction conditions (water content and compaction effort). Figure 5.9 shows the relationship between the erosion rate index and standard compaction dry density ratio [WAN 06]. It can be seen that the hole erosion index is not greatly influenced by the degree of compaction for the range of compaction normally found in engineered dams and levees. The erosion rate index is more influenced by the compaction moisture content and most clearly affected by the degree of saturation.

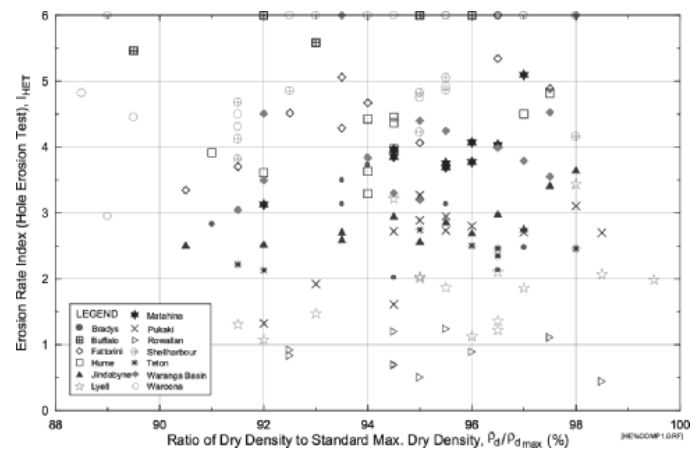

Figure 5.9. HET erosion rate index versus standard compaction dry density ratio [WAN 06]

Hanson and Hunt [HAN 07] compared JET results for a series of three compaction efforts for two soils. Figure 5.10 provides a comparison of the dry density and erodibility results indicating the influence of compaction on the wet and dry sides of optimum. Note that the compaction effort had a significant effect when compacting on the dry side of optimum. From these results, they proposed that acceptable zones of compaction for erodibility might be specified (Figure 5.11). 


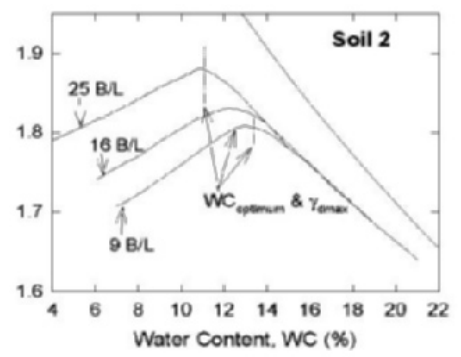

a)

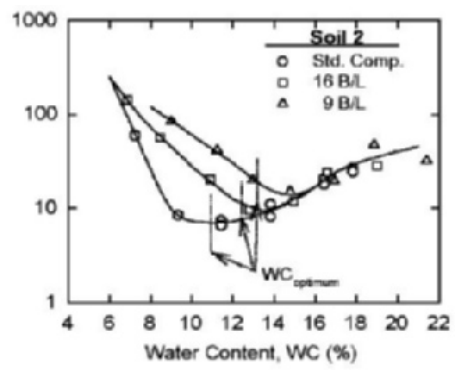

b)

Figure 5.10. Comparison of three compaction efforts for a non-plastic soil a) dry density and b) JET erodibility values [HAN 07]

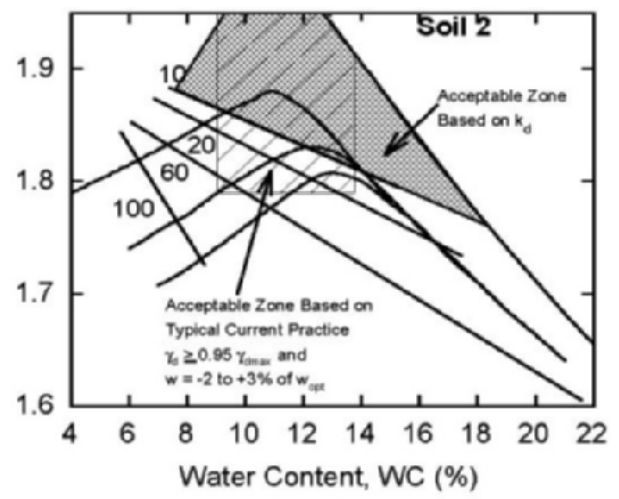

Figure 5.11. Acceptable range of compaction water content and dry density to give lower erosion rates [HAN 07]

Based on this work and experiences in large-scale testing of head cut erosion associated with earthen spillways and overtopped embankments, Hanson et al. [HAN 10b] proposed tables for estimating JET erosion rates and critical shear stress parameters as a function of soil composition, water content at compaction and compaction effort. Rather than using soil classification, they found that the percentage of clay-sized particles was the most important aspect of soil type. 


\begin{tabular}{ccccccc}
\hline $\begin{array}{c}\text { \% Clay } \\
(<0.002\end{array}$ & \multicolumn{2}{c}{$\begin{array}{c}\text { Modified } \\
\text { Compaction }\end{array}$} & $\begin{array}{c}\text { Standard } \\
\text { Compaction } \\
\text { mm })\end{array}$ & $\begin{array}{c}\left(56,250 \mathrm{ft}-\mathrm{lb} / \mathrm{ft}^{3}\right) \\
\left(12,375 \mathrm{ft}-\mathrm{lb} / \mathrm{ft}^{3}\right)\end{array}$ & $\begin{array}{c}\text { Low Compaction } \\
\left(2,475 \mathrm{ft}-\mathrm{lb}_{\mathrm{ft}}{ }^{3}\right)\end{array}$ \\
& $w \geq w$ opt & $w<w$ opt & $w \geq w$ opt $\quad w<w$ opt & $\begin{array}{l}w \geq \\
w \text { OPN }\end{array}$ & $\begin{array}{c}w< \\
w \text { Opt }\end{array}$ \\
\hline$>25$ & 0.05 & 0.5 & 0.1 & 1 & 0.2 & 2 \\
$14-25$ & 0.5 & 5 & 1 & 10 & 2 & 20 \\
$8-13$ & 5 & 50 & 10 & 100 & 20 & 200 \\
$0-7$ & 50 & 200 & 100 & 400 & 200 & 800 \\
\hline
\end{tabular}

Table 5.4. Approximate values of $k_{d}$ from JET as a function of compaction conditions and \% clay [HAN 10b] $\left(1 \mathrm{~cm}^{3} /(\mathrm{N}-\mathrm{s})=0.5655 \mathrm{ft} / \mathrm{h} / \mathrm{psf}\right)$

Tables 5.4 and 5.5 give erodibility parameters based on JET results. Wahl and Lentz [WAH 11] suggested that values representative of HET parameters could be obtained by dividing the suggested $k_{d}$ values by 10 and multiplying the suggested $\tau_{c}$ values by 100 .

\begin{tabular}{|c|c|c|c|c|c|c|}
\hline \multirow[t]{3}{*}{$\begin{array}{l}\% \text { Clay } \\
(<0.002 \mathrm{~mm})\end{array}$} & \multicolumn{2}{|c|}{$\begin{array}{c}\text { Modified } \\
\text { Compaction } \\
\left(56,250 \mathrm{ft}-\mathrm{lb} / \mathrm{ft}^{3}\right)\end{array}$} & \multicolumn{2}{|c|}{$\begin{array}{c}\text { Standard } \\
\text { Compaction } \\
\left(12,375 \mathrm{ft}-\mathrm{lb} / \mathrm{ft}^{3}\right)\end{array}$} & \multicolumn{2}{|c|}{$\begin{array}{l}\text { Low Compaction } \\
\left(2,475 \mathrm{ft}-\mathrm{lb} / \mathrm{ft}^{3}\right)\end{array}$} \\
\hline & $\begin{array}{c}w \\
\geq w_{\mathrm{opt}}\end{array}$ & $\begin{array}{l}w< \\
w_{\mathrm{opt}}\end{array}$ & $\begin{array}{l}w \geq \\
w \mathrm{opt}\end{array}$ & $\begin{aligned} & w \\
< & w_{\mathrm{opt}}\end{aligned}$ & $\begin{array}{l}w \geq \\
w \mathrm{OPN}\end{array}$ & $\begin{array}{l}w< \\
w_{\mathrm{Opt}}\end{array}$ \\
\hline & \multicolumn{6}{|c|}{ Critical shear stress, $\tau_{c}, \mathrm{~Pa}$} \\
\hline$>25$ & 16 & 0.16 & 4 & 0 & 1 & 0 \\
\hline $14-25$ & 0.16 & 0 & 0 & 0 & 0 & 0 \\
\hline $8-13$ & 0 & 0 & 0 & 0 & 0 & 0 \\
\hline $0-7$ & 0 & 0 & 0 & 0 & 0 & 0 \\
\hline
\end{tabular}

Table 5.5. Approximate values of $\tau_{\mathrm{c}}$ from JET as a function of compaction conditions and \% clay [HAN 10b] (1 Pa = 0.0209 psf) 


\subsubsection{Relationship to degree of saturation after compaction}

Wan and Fell [WAN 02, WAN 04a, WAN 04b, WAN 06] and Lim and Khalili [LIM 06, LIM 09] found that most clay soils tested have significantly higher erosion rate indices (slower erosion) and higher critical shear stresses when saturated than in a partially saturated compaction condition.

Figures $5.12-5.14$ illustrate the effect of the degree of saturation on the erosion rate index, using SET, HET, and RCT data, respectively.

Figures 5.12 and 5.13 involve a range of real soils. Figure 5.14 shows the results of testing three soils. Soil $\mathrm{S}$ is a residual granitic soil from the Serpentine Dam, Western Australia, classifying as MH; Soil B is a sandy clay of low plasticity from the Fairbairn Dam, Queensland; Soil F is a clay of low plasticity from the Boggy Creek Dam in Oklahoma, USA; and $50 \%$ of kaolin is an artificial soil consisting of 50\% kaolin and the remainder being fine sandsized particles. It is observed that the erosion rate significantly depends on the degree of saturation for both clay soils.

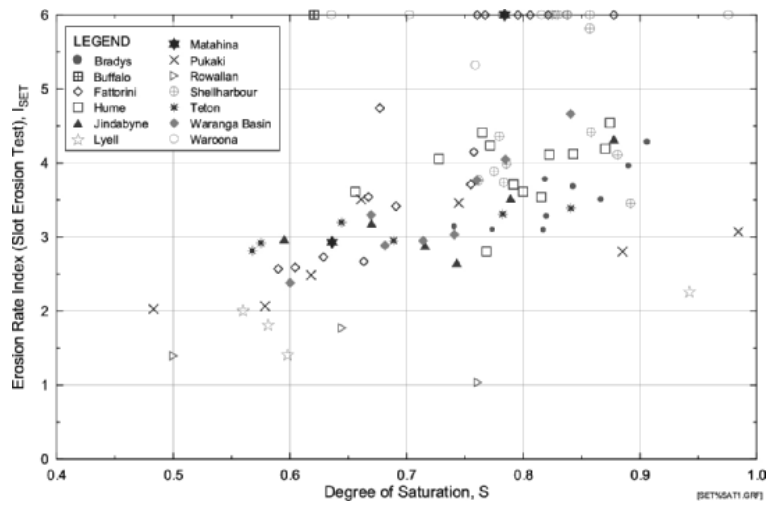

Figure 5.12. Erosion rate index versus degree of saturation from slot erosion tests (SET) [WAN 06] 


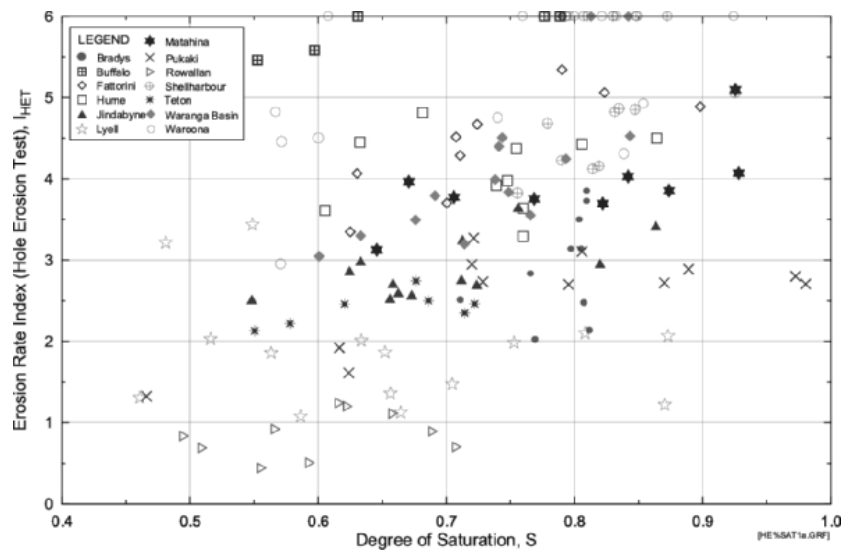

Figure 5.13. Erosion rate index versus degree of saturation from hole erosion tests (HET) [WAN 06]

Saturated soils shown in Figure 5.14 were prepared for testing using triaxial back pressure saturation. The clay soils had $I_{R C T} \approx 3-4$ at the representative compaction and moisture content, and $I_{R C T} \approx 4.5-5.5$ when $90-100 \%$ saturated. There was little change in the erosion rate for clay soils for degrees of saturation above $90 \%$.

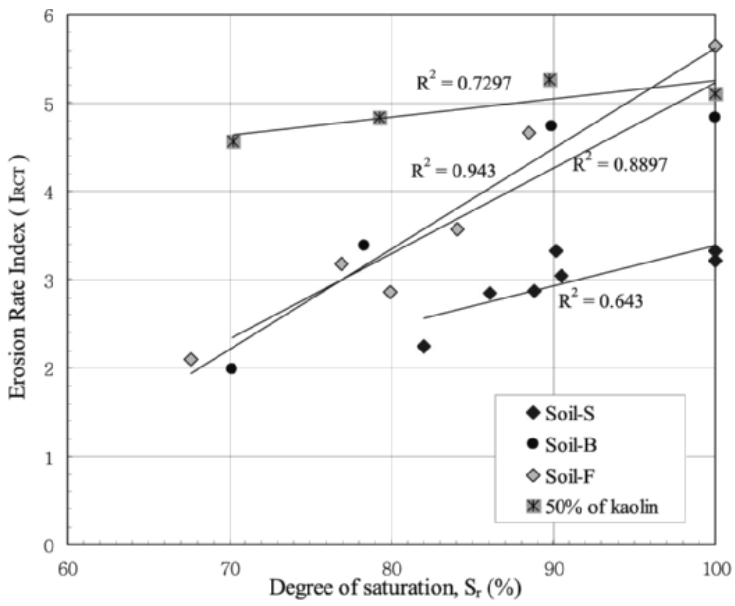

Figure 5.14. Relationship between degree of saturation and erosion rate index (IRCT) for non-dispersive soils [LIM 06] 
This is an important finding because it means that once the core of a dam constructed of clay soil is saturated, it will have a slower rate of erosion and a higher critical shear stress.

As important as this is, this does not apply to silty sand cores such as decomposed and residual granites because there was less dependence on the degree of saturation for these soils. Wan and Fell [WAN 02] indeed noted a similar trend with two other non-plastic residual granitic soils showing little change in the erosion rate with increased degree of saturation.

Regazzoni and Marot [REG 11] evaluated the erodibility of twelve soils by JET. A multivariate analysis was performed and allowed to identify four main physical parameters: compaction, saturation ratio, liquidity limit and dispersivity.

\subsection{Effects of dispersivity and slaking}

\subsubsection{Effects of dispersivity on erosion rate and critical shear stress}

Soils in which the clay particles detach from each other and from the soil structure and go into suspension without a flow of water are called dispersive clays. The dispersivity of a soil is directly related to its clay mineralogy. In particular, soils with a high exchangeable sodium percentage, such as $\mathrm{Na}$ or $\mathrm{Ca}$ with montmorillonite present, tend to be dispersive, while kaolinite and related minerals (e.g. halloysite) are non-dispersive. Soils with illite present tend to be moderately dispersive.

The dispersivity depends also on the pore water chemistry. Low pore water salt concentrations lead to greater dispersivity and high salt concentrations can 
suppress dispersion in susceptible soils. Hence, percolation of a saline soil with fresh water can lead to dispersion.

The mechanism of dispersion is related to the fact that dispersive clay molecules carry a negative charge on their surface. These charges attract positively charged cations in the soil pore water, for example from $\mathrm{Na}$ ions in $\mathrm{NaCl}$.

When two clay particles come near each other, the potential fields overlap, leading to repulsion if the particles are close enough. These repulsive forces are counteracted by Van der Waals attractive forces as shown in Figure 5.15. If the repulsive forces are greater than the Van der Waals forces, the soil will disperse. In cases where the repulsive forces are small, the Van der Waals attractive forces dominate and flocculation results.

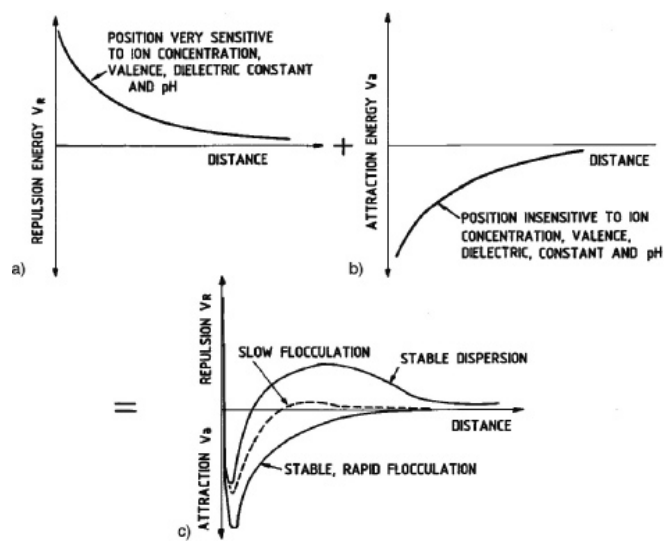

Figure 5.15. Interaction of a) repulsive and b) Van der Waals attractive forces to give c) curves of net energy of repulsion or attraction ([FEL 05], adapted from [MIT 76])

The repulsive forces in the diffuse double-layer are affected by several factors:

1) Electrolyte concentration: as shown in Figure 5.16, a high concentration of dissolved salt in the soil water leads to 
a smaller diffuse double-layer (as the greater concentration of cations $\left(\mathrm{Na}^{+}\right)$more readily overcomes the negative charge on the clay surface). Hence, the repulsive forces are lower.

2) Cation valence: exchange of $\mathrm{Na}^{+}$cations with $\mathrm{Ca}^{++}$ cations leads to a smaller, higher charge density diffuse double-layer and hence lower repulsive forces.

Other factors which affect the diffuse double-layer include:

- dielectric constant of the electrolyte;

- temperature.

More details are given in Fell et al. [FEL 05] and Mitchell [MIT 76, MIT 93].

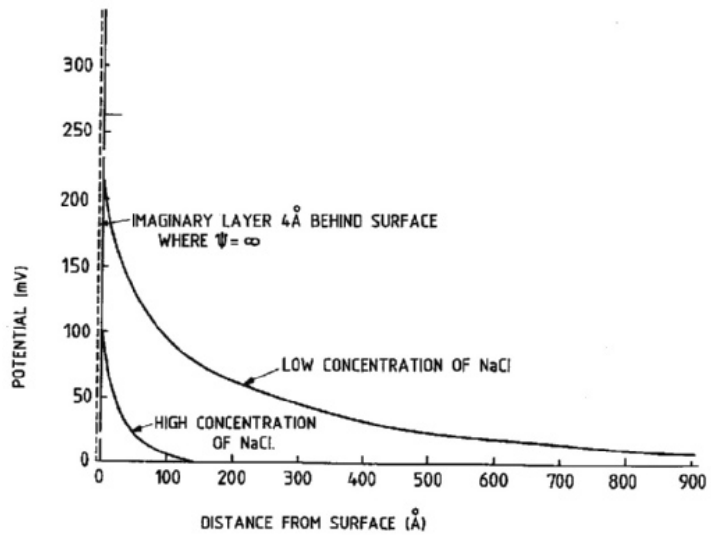

Figure 5.16. Effect of electrolyte concentration on diffuse double-layer potential for montmorillonite ([FEL 05], adapted from [MIT 76])

Soils which show dispersive behavior, that is soils classified as Emerson Crumb Class 1 or 2, and Pinhole Dispersion D1 and D2, will have a very low critical shear stress if the eroding fluid is sufficiently free of salts which might otherwise suppress dispersion. 
It should be noted that under flood conditions, the salt content of the water in the reservoir is likely to drop; so, tests conducted with reservoir water may be unconservative. If in doubt with dispersive soils, it is best to assume that the reservoir water will not inhibit dispersion and rely on the results of tests using distilled water.

Lim [LIM 06] showed that for RCT tests, the erosion rate index is not greatly affected by whether the soil is dispersive after the initially rapid part of the erosion process. So, the major effect of dispersion is on the critical shear stress at which erosion initiates, not on the rate of erosion.

\subsubsection{Effects of slaking on erosion rate and critical shear stress}

The term "slaking" or "soil slaking" is defined as "disintegration of unconfined soil after exposure to air and subsequent immersion in a fluid, usually water; no external confining pressure is assumed to act over the soil prior to immersion" [MOR 77]. Lim [LIM 06] and Lim and Khalili [LIM 09] showed that the slaking process was correlated strongly to the degree of saturation of the soil, with the slaking rate being up to $30-50$ times lower for soils at $100 \%$ degree of saturation than for soils at $70 \%$ degree of saturation (Figure 5.17). This corresponds with the behavior of the erosion rate index for clay soils.

As shown in Figure 5.18, they also proved a strong correlation between the rates of slaking from a sample held statically in water to the erosion rate index from the RCT $\left(I_{R C T}\right)$. These are important findings as they help explain the actual mechanics of the erosion process being strongly linked to slaking.

Vallejo [VAL 11] indicates that slaking occurs in shale as water is drawn into the micropores by capillary tension, 
compressing the air in the micropores. This increase in pore air pressure is able to break bonds between soil particles, producing the observed disintegration of the soil.

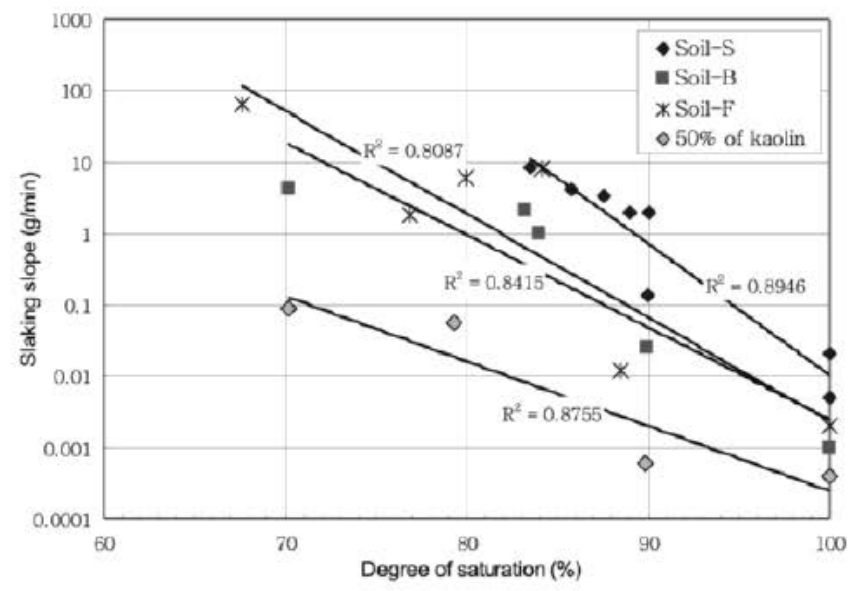

Figure 5.17. Relationship between the degree of saturation and slaking slope for non-dispersive clay soils [LIM 06]

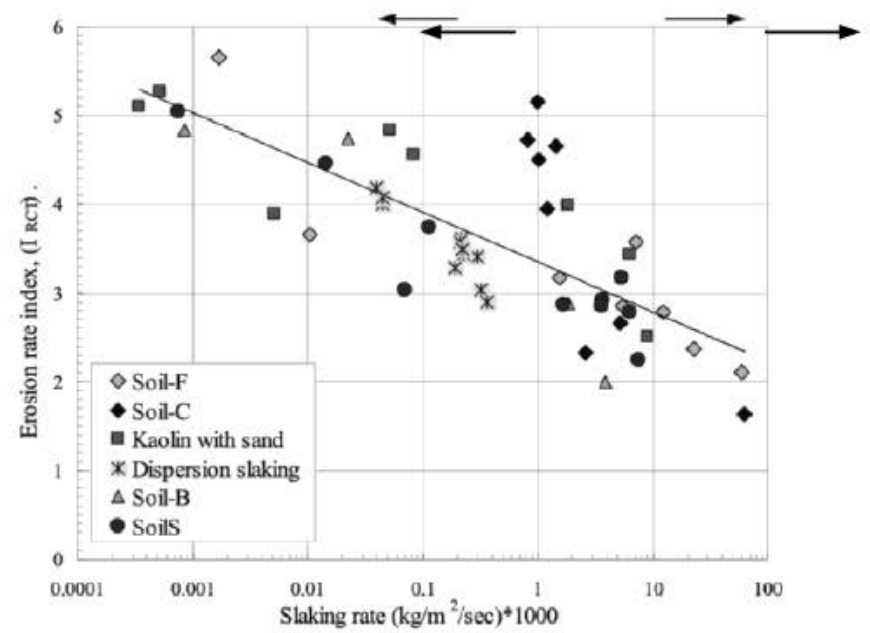

Figure 5.18. The range of erosion rate index for RCT and slaking rate [LIM 06] 


\subsection{Modifications of soil erosion properties}

\subsubsection{Modification by lime}

Lime treatment of soils is a technique widely used for soil improvement and stabilization for construction of roads, highways, railways and platforms [LIT 95]. Lime has been used for five decades for improving and re-using the soils in levees, earth dams and flood dikes not only in the United States ([GUT 78, KNO 87, PER 77, TOW 79]), but also in Australia [ING 72]. The treatment of soil with lime was reported to solve erosion problems due to dispersive soils, to prevent the shrinkage-swelling phenomenon coming from heavy plastic soils and, therefore, to stabilize the slopes or road subgrades.

Fine clay or loam soils are sometimes difficult to use for constructing embankments or platforms because of their sensitivity to water, low bearing capacity when wet and the difficulty in compacting them. Quicklime added to fine clay or loam soil overcomes these difficulties and enables these soils to be reused in infrastructure projects. This is mainly done for road construction.

The addition and mixing of lime leads to a series of immediate and mid- to long-term effects on the silty and clayey soils. Several objectives can be reached through lime addition. In the case of quicklime treatment, the direct effect is the reduction in the moisture content of the soils:

- by the hydration reaction of quicklime, combining some amount of water contained in the soils, and leading also to vaporization of some of the water by the heat generated by the following exothermic reaction:

$$
\mathrm{CaO}+\mathrm{H}_{2} \mathrm{O} \rightarrow \mathrm{Ca}(\mathrm{OH})_{2}+\text { heat }(1,155 \mathrm{~kJ} / \mathrm{kg} \mathrm{CaO})
$$

- by the addition of dry powder to the soil reducing the water:solid ratio; 
- during mixing operations, soil aeration also can lead to a supplementary water loss.

The addition of slaked calcic lime $\left[\mathrm{Ca}(\mathrm{OH})_{2}\right]$ only affects the soil moisture content by increasing the proportion of dry material, while milk of lime (suspension of hydrated lime in water) is applied when dry soil needs to be treated for specific neutralization of the clayey fractions in order to avoid swelling and shrinkage.

Geotechnical characteristics of soils are immediately affected by lime addition. This is a consequence of the displacement of monovalent or smaller cations located at the surface and between the clay platelets, by $\mathrm{Ca}^{2+}$ ions coming from calcic lime. This phenomenon leads to a rearrangement of the contacts between particles to compensate the electrostatic changes. This is known as clay flocculation.

The flocculation modifies the general behavior and characteristics of soil with significant reduction in clay activity as the plasticity index is reduced. This consequence of particle flocculation can be concomitant with water reduction, changing the compaction characteristics of the soil. It can also inhibit slaking and dispersion as shown in Figure 5.19.

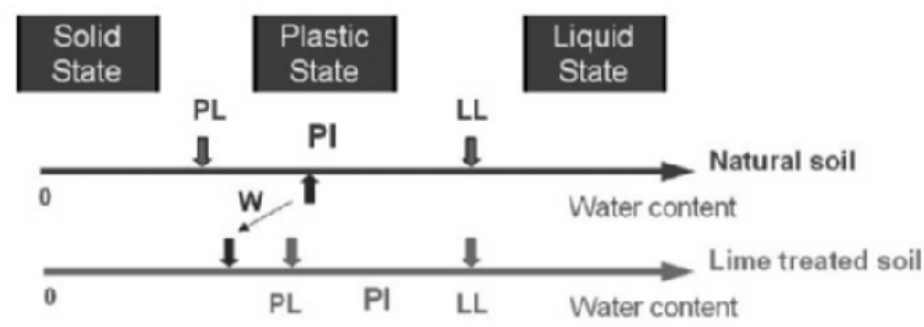

Figure 5.19. Modifications induced by lime treatment on a soil, simultaneous reduction of plasticity index (PI) and water content; $P L=$ plastic limit,$L L=$ liquid limit [HER 12a] 
At a certain time after compaction, a recombination of calcium, dissolved silica and alumina coming up from clay species and water can occur. This reaction is favored at high $\mathrm{pH}$ values, which are necessary for the dissolution of specific clay compounds, and sufficient lime dosages that guarantee lime availability. The products of this "pozzolanic" reaction are similar to cementitious compounds: calcium silicate hydrates and calcium aluminate hydrates (cementitious notation: $\mathrm{C}=\mathrm{CaO}, \mathrm{S}=\mathrm{SiO}_{2}, \mathrm{~A}=\mathrm{Al}_{2} \mathrm{O}_{3}, \mathrm{H}=\mathrm{H}_{2} \mathrm{O}$ ):

$$
\begin{aligned}
& x \mathrm{Ca}^{2+}+\mathrm{y} \mathrm{SiO}_{2}+\mathrm{z} \mathrm{H} 2 \mathrm{O}+\mathrm{x} \mathrm{OH}^{-} \rightarrow \mathrm{C}_{\mathrm{x}} \mathrm{S}_{\mathrm{y}} \mathrm{H}_{\mathrm{z}} \\
& \mathrm{x} \mathrm{Ca}^{2+}+\mathrm{y} \mathrm{Al}_{2} \mathrm{O}_{3}+\mathrm{z} \mathrm{H}_{2} \mathrm{O}+\mathrm{x} \mathrm{OH}^{-} \rightarrow \mathrm{C}_{\mathrm{x}} \mathrm{A}_{\mathrm{y}} \mathrm{H}_{\mathrm{z}}
\end{aligned}
$$

This reaction develops at the mid- or long-term and increases the soil compressive strength, tensile strength, and elastic modulus. The lime-treated soil can be considered as a "cemented" material in the sense that the particle assembly is realized by the cohesive bonds induced by the lime action.

The ASTM D 6572-06 Standard (“Crumb-test") was used to demonstrate the non-dispersive behavior of an initially dispersive silty soil $(P I=11)$ treated with $2-3 \%$ quicklime [HER 12a]. This improvement was still visible three years after treatment. An enhanced Crumb test was also performed on silty soil (small cylinders, untreated and treated with $2 \%$ lime). The untreated cylinder collapsed after 15 minutes of immersion, whereas no degradation occurred on the lime-treated sample, even after 45 hours of immersion (Figure 5.20).

The resistance to erosion of a clay-like silt treated with $2 \%$ lime was examined [HER 12b, HER 12c]. The tested material is an A2 silt from a river levee in the South of France, which contains $19 \%$ sand and $30 \%$ clay $\left(I_{P}=11\right.$, $\left.W_{O P N}=18 \%\right)$. Several HET tests were carried out at the geotechnical laboratory of Irstea at different curing times. The erosion rate, which depends on the tangential stress, is 
represented in Figure 5.21. Figure 5.22 shows the erosion velocity depending on the outflow velocity. The erosion threshold of the non-treated silt is around $2 \mathrm{~m} / \mathrm{s}$. The erosion threshold of the treated silt after 14 days of curing time is around $10 \mathrm{~m} / \mathrm{s}$.

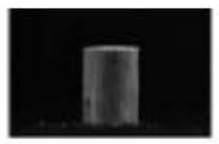

Initial state

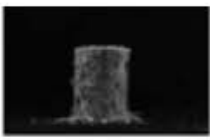

$5 \mathrm{~min}$

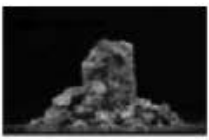

$15 \mathrm{~min}$

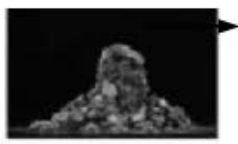

$45 \mathrm{~min}$

Untreated specimens

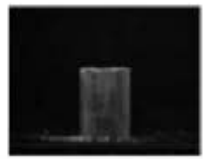

Initial state

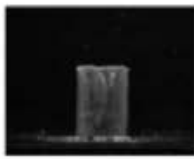

5 hours

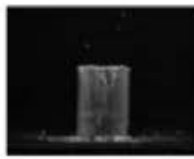

15 hours

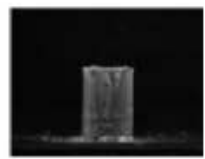

45 hours

$2 \%$ dime treated specimens

Figure 5.20. Enhanced Crumb test performed on a silty soil ( $P I=11)$, untreated (above, scale in minutes), and treated with $2 \%$ lime (below, scale in hours) [HER 12a]

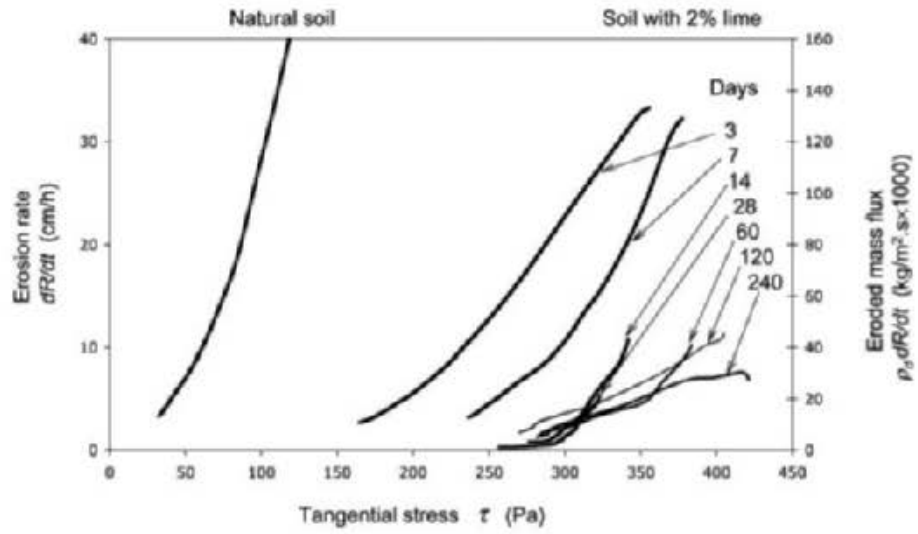

Figure 5.21. Erosion rate versus hydraulic shear stress for a claylike soil at different curing times [HER 12b, HER 12c] 


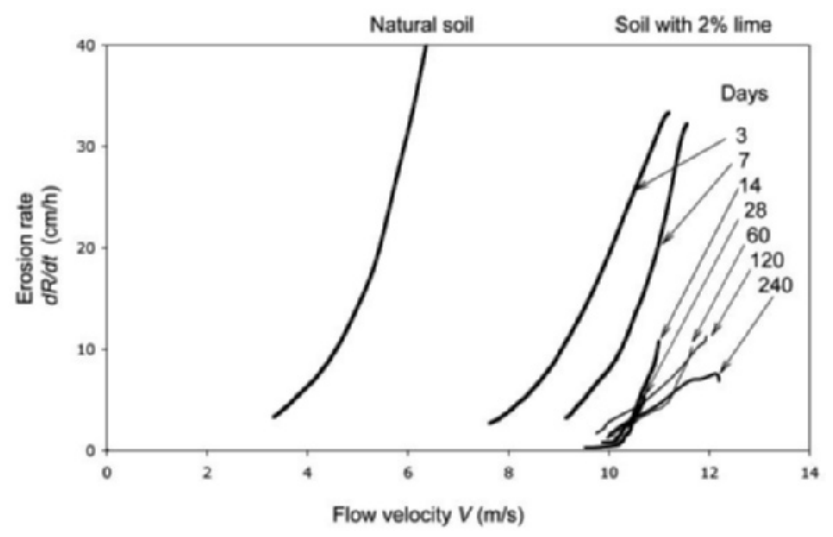

Figure 5.22. Erosion rate versus hydraulic velocity at different curing times [HER 12b, HER 12c]

The influence that the curing time has on the critical stress and erosion index is represented in Figure 5.23. These results allow us to quantify the improvement of the resistance to erosion. The natural soil has a critical stress of $53 \mathrm{~Pa}$ and an erosion rate index of 3.37. During the first 14 days, the critical stress is multiplied by six, while the erosion rate index decreases slightly to three. Then, the critical stress decreases slightly to $250 \mathrm{~Pa}$, while the erosion rate index goes up to 4.6 (equivalent to the erosion coefficient being divided by 40 ).
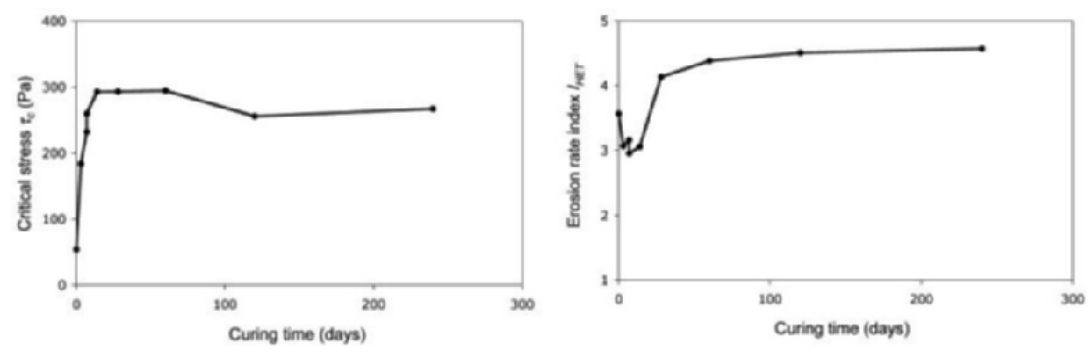

Figure 5.23. Influence of the curing time on the critical stress and on the erosion rate index [HER 12b, HER 12c] 


\subsubsection{Modification by cement}

In the case of a granular and non-cohesive soil, the addition of cement will result in a cementing of the soil and an increase in the compressive strength.

Indraratna et al. [IND 10] carried out tests on silty sand to which cement between $0.5 \%$ and $3 \%$ was added. They performed erosion tests in a setup similar to an HET, but with a $10 \mathrm{~mm}$ diameter hole, and tensile strength tests.

Figure 5.24 shows the results of this experimentation. It is observed that the addition of cement reduces the rate of erosion and also increases the critical shear stress as indicated by the shifting of intercept of the data on the hydraulic shear stress axis.

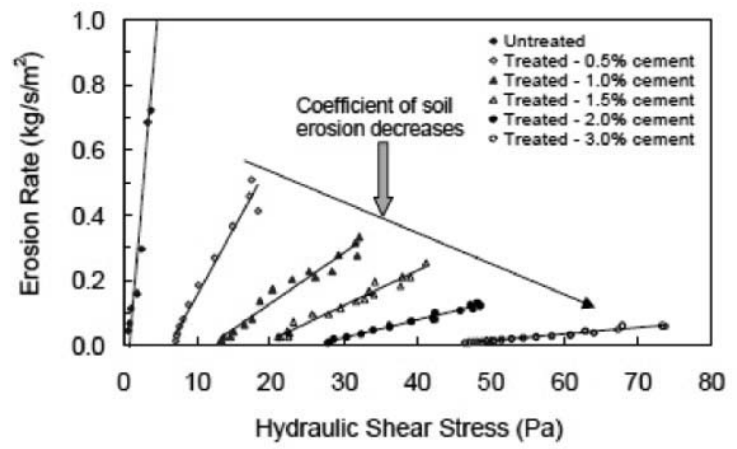

Figure 5.24. Erosion rate versus hydraulic shear stress for a silty sand modified by the addition of cement [IND 10]

\subsection{Bibliography}

[BEN 12a] BENAHMED N., BONELLI S., "Investigating concentrated leak erosion behaviour of cohesive soils by performing hole erosion tests", European Journal of Environmental and Civil Engineering, vol. 16, no. 1, pp. 43-58, 2012. 
[BEN 12b] Benahmed N., Chevalier C., Bonelli S., "Concentrated leak erosion", Erosion of Geomaterials, Chapter 5, ISTE Ltd, London and John Wiley \& Sons, New York, pp. 155-186, 2012.

[BON 08] BONELLI S., BRIVOIS O., "The scaling law in the hole erosion test with a constant pressure drop", International Journal for Numerical and Analytical Methods in Geomechanics, vol. 32, pp. 1573-1595, 2008.

[BON 11] Bonelli S., BenAHMEd N., "Piping flow erosion in water retaining structures", International Journal on Hydropower and Dams, vol. 18, no. 3, pp. 94-99, 2011.

[BRI 08a] BRIAUD J.-L., "Case histories in soil and rock erosion: Woodrow Wilson Bridge, Brazos River Meander, Normandy Cliffs, and New Orleans Levees", The 9th Ralph B. Peck Lecture, Journal of Geotechnical and Geoenvironmental Engineering, vol. 134, no. 10, pp. 1425-1447, 2008.

[BRI 08b] BRiaUd J.-L., Chen H.-C., Govindasamy A.V., et al., "Levee erosion by overtopping in New Orleans during the Katrina Hurricane", Journal of Geotechnical and Geoenvironmental Engineering, vol. 134, no. 5, pp. 618-632, 2008.

[FEL 03] Fell R., Wan C.F., Cyganiewicz J., et al., "Time for development of internal erosion and piping in embankment dams", ASCE Journal of Geotechnical and GeoEnvironmental Engineering, vol. 129, no. 4, pp. 307-314, 2003.

[FEL 05] Fell R., MacGregor P., Stapledon D., et al., Geotechnical Engineering of Dams, Taylor \& Francis, 2005.

[FEL 08] FELL R., Foster M., DAVIDSON R., et al., Unified method for estimating probabilities of failure of embankment dams by internal erosion and piping, UNICIV Report R 446, School of Civil and Environmental Engineering, University of New South Wales, Sydney, Australia, 2008.

[GUT 78] GUTSCHICK K.A., "Lime stabilization under hydraulic conditions", 4th Lime Congress, Hershey, PA, pp. 1-20, 1978.

[HAN 89] HANSON G. J., "Channel erosion study of two compacted soils", Transactions of the ASAE, vol. 32, no. 2, pp. 485-490, 1989. 
[HAN 01] HANSON G.J., SIMON A., "Erodibility of cohesive streambeds in the loess area of the Midwestern USA", Hydrologiacl Processes, vol. 15, no. 1, pp. 23-28, 2001.

[HAN 01] Hanson G.J., Robinson K.M., CoOK K.R., "Prediction of headcut migration using a deterministic approach", Transactions of the ASAE, vol. 44, no. 3, pp. 525-531, 2001.

[HAN 04] HANSON G.J., COOK K.R., “Apparatus, tests procedures, and analytical methods to measure soil erodibility in-situ", Applied Engineering in Agriculture, vol. 20, no.4, pp. 455-462, 2004.

[HAN 07] HANSON G.J., HUNT S.L., "Lessons learned using laboratory jet method to measure soil erodibility of compacted soils", Applied Engineering in Agriculture, vol. 23, no. 3, pp. 305-312, 2007.

[HAN 10a] HANSON G.J., TEJRAL R.D., HUNT S.L., et al., "Internal erosion and impact of erosion resistance", Proceedings of the United States Society on Dams, 30th Annual Conference, Sacramento, CA, 12-16 April 2010.

[HAN 10b] HANson G.J., WAHL T.L., TEMPle D.M., et al., "Erodibility characteristics of embankment materials", Dam Safety 2010, Proceedings of the Association of State Dam Safety Officials Annual Conference, Seattle, WA, 19-23 September 2010. (CDROM).

[HAN 11] Hanson G.J., TEMPle D.M., HunT S.L., et al., "Development and characterization of soil material parameters for embankment breach", Applied Engineering in Agriculture, vol. 47, no. 4, pp. 587-595, 2011.

[HER 12a] Herrier G., Lelong V., Lesueur D., et al., Soil treatment for dikes, SOTREDI final report, Lhoist Eds, Limelette, Belgium, pp. 1-103, 2012.

[HER 12b] Herrier G., Lesueur D., PuiAtTi D., et al., "Lime treated materials for embankment and hardfill dams", International Symposium on Dams for a Changing World, Kyoto, Japan, 5 June 2012. 
[HER 12c] Herrier G., Lesueur D., Puiatti D., et al., "Lime treated soils as an erosion-resistant material for hydraulic earthen structures", 6th International Conference on Scour and Erosion, Paris, France, pp. 97-104, 27-31 August 2012.

[HUN 05] Hunt S.L., HANSON G.J., CoOK K.R., et al., "Breach widening observations from earthen embankment tests", Transactions of the ASAE, vol. 48, no. 3, pp. 1115-1120, 2005.

[HUN 07] Hunt S.L., HANson G.J., TEMPLE D.L., et al., "Earthen embankment internal erosion research", Dam Safety 2007, Proceedings of the 24th Annual Meeting of the Association of State Dam Safety Officials, Austin, TX, 9-12 September 2007.

[IND 10] INDRARATNA B., MAHAMUd M., VinOD J.S., et al., "Stabilization of an erodible soil using a chemical admixtures", in Bouassida M., HAMDI E, SAID I. (eds), Proceedings of the 2nd International Conference on Geotechnical Engineering, ENIT, pp. 45-54, 2010.

[ING 72] Ingles O.G., Metcalf J.B., Soil Stabilization, Butterworths, 1972.

[KNO 87] KNODEL P.C., Lime in canal and dam stabilization, Report No GR-87-10, U.S. Bureau of Reclamation, pp. 1-21, 1987.

[LIM 06] LIM S.S., Experimental investigation of erosion in variably saturated clay soils, $\mathrm{PhD}$ Thesis, School of Civil and Environmental Engineering, University of New South Wales, Sydney, Australia, 2006.

[LIM 09] LIM S.S, KHALILI N., "An improved rotating cylinder test design for laboratory measurement of erosion in clayey soils", Geotechnical Testing Journal, vol 32, no. 3, pp. 1-7, 2009.

[LIT 95] LitTle D.L., Handbook for Stabilization of Pavement Subgrades and Base Courses with Lime, Kendall/Hunt Publishing Company, Dubuque, Iowa, 1995.

[MAR 11] MARot D., Regazzoni P.L., WaHL T., "Energy based method for providing soil surface erodibility rankings", ASCE Journal of Geotechnical and GeoEnvironmental Engineering, vol. 137, no. 12, pp. 1290-1294, 2011. 
[MIT 76] Mitchell J.K., Fundamentals of Soil Behavior, John Wiley \& Sons, 1976.

[MIT 93] Mitchell J.K., Fundamentals of Soil Behavior, 2nd edition, John Wiley \& Sons, 1993.

[MOR 77] MORIWAKI Y., MitcheLl J.K., "The role of dispersion in the slaking of intact clay", ASTM Special Technical Publications, vol. 623, pp. 287-302, 1977.

[PER 77] PERRY J.P., "Lime treatment of dams constructed with dispersive clay soil", Transactions of the ASAE, vol. 20, pp. 1093-1099, 1977.

[REG 09] REGazzoni P.L., Confrontation et analyse d'érodimètres et caractérisation de la sensibilité à l'érosion d'interface, $\mathrm{PhD}$ Thesis, University of Nantes, 2009.

[REG 11] REGAZzoni P.-L, MARot D., "Investigation of interface erosion rate by jet erosion test and statistical analysis", European Journal of Environmental and Civil Engineering, vol. 15, no. 8, pp. 1167-1185, 2011.

[REG 13] REGAZZoni P.-L., MAROT D., "A comparative analysis of interface erosion tests", Natural Hazards, 2013. In press.

[TEM 85] TEMPLE D.M., "Stability of grass-lined channels following mowing", Transactions of the ASAE, vol. 28, no. 3, pp. 750-754, 1985.

[TOW 79] TOWNSEND F.C., Use of lime in levee restoration, Vicksburg: US Army Engineer Waterways Experiment Station, Report GL-79-12, p. 102, 1979.

[VAL 11] VALLEJO L.E., "Mechanics of slaking of shales", Geomechanics and Engineering, vol. 3, no. 3, pp. 219-232, 2011.

[WAH 08a] WAHL T. L., ERDOGAN Z., Erosion indices of soils used in ARS piping breach tests, Hydraulic Laboratory Report HL-2008-04, U.S. Department of the Interior, Bureau of Reclamation, Denver, CO, p. 142, 2008.

[WAH 08b] Wahl T.L., Regazzoni P., Erdogan Z., Determining erosion indices of cohesive soils with the hole erosion test and jet erosion test, Dam Safety Technology Development Report DSO-08-05, U.S. Department of the Interior, Bureau of Reclamation, Denver, CO, p. 45, 2008. 
[WAH 11] WAHL T.L., LENTZ D.J., Physical hydraulic modeling of canal breaches, Hydraulic Laboratory Report HL-2011-09, U.S. Department of the Interior, Bureau of Reclamation, Denver, CO, p. 56, 2011.

[WAN 02] WAN C.F., FELL R., Investigation of internal erosion and piping of soils in embankment dams by the slot erosion test and the hole erosion test, UNICIV Report No. R-412, University of New South Wales, Sydney, Australia, July 2002.

[WAN 04a] WAN C.F., FELL R., "Investigation of rate of erosion of soils in embankment dams", Journal of Geotechnical and Geoenvironmental Engineering, vol. 30, no. 4, pp. 373-380, 2004.

[WAN 04b] WAN C.F., FELL R., "Laboratory tests on the rate of piping erosion of soils in embankment dams", Geotechnical Testing Journal, vol. 27, no. 3, pp. 295-303, 2004.

[WAN 06] WAN C.F., Experimental investigation of piping erosion and suffusion of soils in embankment dams and their foundations, PhD Thesis, School of Civil and Environmental Engineering, University of New South Wales, Sydney, Australia, 2006. 